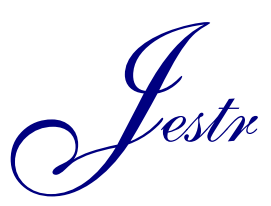

\title{
Degradation Behavior of Silk Fibroin Biomaterials - A Review
}

\author{
Purnomo $^{1}$, Putu Hadi Setyarini ${ }^{2}$ and Dwi Sulistyaningsih ${ }^{3}$ \\ ${ }^{I}$ Dept. of Mechanical Engineering, Universitas Muhammadiyah Semarang, Indonesia \\ ${ }^{2}$ Dept. of Mechanical Engineering, Brawijaya University, Malang, Indonesia \\ ${ }^{3}$ Dept. of Mathematics Education, Universitas Muhammadiyah Semarang, Indonesia
}

Received 18 January 2019; Accepted 10 September 2019

\begin{abstract}
Silk fibroin-based biomaterials have developed widely for biomedical applications including soft tissue engineering and bone implants. Controlling the degradation rate is very notable in maintaining the performance of biomaterials in carrying out their functions. This review was focused on the process of biodegradation of silk fibroin and its controllers including among other factors that influence the degradation process, mechanisms, behavior, the role of ultraviolet (UV) radiation, and the effect of molecular weight. All studies in this paper provide more in-depth knowledge about the biodegradation of silk fibroin enzymatically as well as UV radiation effect.
\end{abstract}

Keywords: silk fibroin, degradation, mechanism, ultraviolet radiation

\section{Introduction}

Silk is a kind of natural protein fiber produced by members of the Arachnida class (spider species) and by animals in Lepidoptera's order like butterflies and consists of fibroin and sericin $[1,2,3]$. Both are two disparate protein families. Single silk filaments are arranged fibroin in the microfibrils form. The silk string are formed from each of these filaments derived from silk glands besieged by sericin skin. Silks have been considerably used as biomaterials especially in tissue engineering such as regenerated silk fibroin [4-15] as well as degummed silk [16-18]. Various forms of materials made of fibroin and sericin such as films, hydrogels, particles, and fibers [19-21] have been developed through several methods such as electrospinning [22], Electron-beam lithography $[23,24]$, printing [25-28], and photolithography [29,30]. The latter method is the most interesting for compatible biomechanics [31-35].

Silk fiber has been widely used for various human interests, especially in the textile industry. At present, silk fiber has been developed for biomedical applications because of its biocompatibility and biodegradability [36-39]. As a biomaterial, degradation is of particular concern because the consequences it causes are very detrimental in its implementation. Its degradation is characterized by changes in properties including silk to be lighter, the color changes to yellowish, and its mechanical strength decreases so that it does not fit the needs.

In biomedical applications, especially in tissue engineering, degradation is very important to study in order to assess material performance in carrying out its functions [40,41]. Silk fibroin has been considerably developed as a biomedical material in consequence of its biocompatibility,

\footnotetext{
*E-mail address: purnomo@unimus.acid

ISSN: 1791-2377 @ 2019 School of Science, HHU. All rights reserved.

doi:10.25103/jestr.125.08
}

flexibility, morphological suitability and mechanical properties, and excellent environmental stability [42-44]. Because of these characteristics, silk fibroin is very prospective as a biomaterial in tissue engineering $[45,46]$. The development of silk fibroin properties is very important in order to meet various application requirements. Therefore, researchers have carried out a variety of studies aimed at extending the application of silk fibroin from hydrophobic to hydrophilic material $[47,48]$, as well as from filaments to films, sheets, and scaffolds [46,49,50].

In carrying out its functions, the performance of fibroin silk is very limited by its own degradation. Control of the degradation process of silk fibroin is still an uncertain problem [51]. However, silk fibroin conditioning in a $\beta$-sheet structure can be considered a major factor in stabilizing silk fibroin especially in water-containing environments. In terms of controlling degradation behavior, factors that can be expected to affect silk fibroin degradation need to be explored more intensively. Regarding this, $\mathrm{Lu}$ [52] has reported that the stability of silk fibroin from the formation of stable $\beta$-sheets in water has been improved without increasing $\beta$-sheets. In addition, degradation of silk films occurs faster in enzyme solutions.

\section{Silk Fibroin Structure}

In protein-based materials, their properties are primarily determined by various inter-molecular interactions. As a protein-based material, silk consists of two structural components, namely amorphous with random coils (Silk I) and crystals with $\beta$-sheets crystals (Silk II) $[4,53]$. The structure of silk II can be obtained by changing the silk I using potassium phosphate and methanol treatment [54-56]. With various treatments, silk fibers can be arranged to be stored in various forms, including fibers, powders, sponges, and hydrogels. Therefore, silk fibers are very potential to be used to build structures in varied scales, from nano to macro $[4,57]$. 
Many reseacher have observed the indwelling structure and related functions of the silk fibroin [58-60]. Based on these works, various structures are found in silk fibroin-based materials. Silk fibroin is an immense molecule dominated by about two thirds of the crystals and one-third is an amorphous region. The crystalline part consists of recurrent amino acids (-GlyAla-Gly-Ala-Gly-Ser-), creating antiparallel $\beta$-sheets and is the key to the stability and mechanical characteristic of the silk fibroin [61-63]. Silk fibroin was able to portray a unique biological function due to their powess to form structures in many kinds such as film, porous, fiber, and threedimensional. The mechanical properties of the silk are strongly controlled by their structural which may contain various features such as nanofibril [64-70], skin-core, crystallinity, crystal size distribution as well as orientation of molecular level [71].

The researchers assume that silk as a semi-crystalline biopolymer with regularly arranged nanocrystal is surrounded by a formless matrix as depicted in Fig. 1. From that image, it can be seen that an irregular part called amorphous is richer with amino acids that surround the region crystal. This phenomenon shows that different degrees of crystallinity are produced by a small fraction of the state of the secondary silk fibroin structure manipulated by the introduction of hydrophobic side groups [72]. In general, the amorphous arrangement and the antiparallel $\beta$-sheet type on the secondary structure of silk fibers are formed due to the presence of hydrogen bonds between adjacent peptide chains [73].

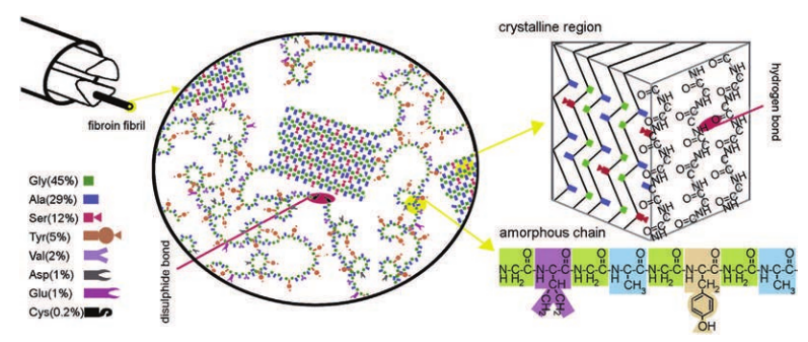

Fig. 1. Schematic illustration showing primary and secondary structures in silk fibroin. Reproduced from Ref.[74].

\section{Degradation behavior of silk fibroin biomaterials}

\subsection{Factors affecting silk fibroin degradation}

In our previous review [75] it has been reported that silk fibroin has the potential to be applied as reinforcement in implantable biomaterials. However, as a natural protein, proteolytic enzymes can degrade silk fibroin catalytically so as to reduce silk fibroin properties. The level of degradation is strongly influenced by various factors including physical, chemical and biological factors. These factors are strongly related to molecular weight [36, 76-80] and secondary structures $[36,79,80]$ from silk fibroin, and processing method [81-83]. In terms of the relationship between enzyme solution and degradation, Zuo et al. [84] have reported that in the solution of the actinomycetes enzyme, regenerated silk fibroins are degraded faster than natural silk fibers. This occurs because molecular weight and mechanical properties decrease during the regeneration process [84].

The degradable process on silk fibroin is influenced by the enzyme properties. It has been reported by several researchers $[85,86]$ that the majority of low molecular weight proteolytic enzymes and non-dense structures have better ability to increase the rate of silk fibroin degradation. This phenomenon indicates that the molecular weight and structure of silk fibroin is closely related to the degradation behavior. In other words, the structure and molecular weight is a factor that greatly influences the degradation process. This means that the non-compact structure and low molecular weight make it easier for the enzyme to coalesce on the silk surface which then forms hydrolysis behavior. Due to the nature of silk fibroin is degraded by enzymes, controlling the availability and content of enzymes becomes very important in managing the degradation rate $[87,76,85]$. It has also been reported that degradation behavior can be controlled through chemical modification [88-90].

In porous fibroin, the degradation behavior is strongly related to processing conditions [91] and its structural properties $[76,47]$. Therefore it should be suspected that both of these are related to the level of surface roughness and crystallinity distribution [92]. Thus, the degradation behavior of silk fibroin can be set by controlling crystallinity [93], molecular weight distribution and porosity [94]. In the case of silk fibroin that is applied as an implantable biomaterial, it must be noted that function requirements, mechanical integration, and physiology are the main considerations in the control of degradation in silk fibroin materials. In this case, controlling the rate of degradation is very important in designing the function of the implanted biomaterial. Therefore the degradation rate must be synchronous with the associated growth rate of body tissue [95,76,53]. Some researchers $[96,76]$ has reported that in vivo absorption of silk fibroin is strongly influenced by the location of implants.

Many researchers [97,82] reported that the highest degradation rate occurred in silk fibroin materials with the lowest content of $\beta$-sheets. Whereas in porous silk material, samples incubated in a solution of $\alpha$-chymotrypsin and collagenase IA at $37 \mathrm{oC}$ for 15 days experienced a loss of $32 \%$ and 52\%, respectively [98]. You et al. [99] reported that the degree of crosslinking of more than $90 \%$ convey the same degradability as $75 \%$ of films with ethanol treatment. Furthermore, in vivo test for 28 days showed that the decrease in crosslinking degree from $90 \%$ to $78 \%$ significantly increased the degradation ratio from 4 wt.\% to 18 wt.\%, respectively. They concluded that degradability was strongly correlated with a crosslinking degree lower than $90 \%$. In other words, the rate of degradation is efficiently controlled by the crosslinking process.

\subsection{Degradation mechanism}

In general, the polymer degradation process occurs in four steps: (i) the hydration process. The water provided by the outside media penetrates the polymer which is often functioned as a matrix and influences the secondary strength thus encouraging relaxation and decreasing the glass transition temperature of the material [100]; (ii) The initial degradation process is the occurrence of a covalent bond zone that starts in the hydrated polymer area. This process occurs after hydrolysis in the polymer matrix which is facilitated by an increase in the carboxylic end group [101], resulting in a decrease in the molecular weight of the polymer resulting in loss of mechanical strength; (iii) Development of degradation. The polymer has a significant mass loss caused by a continued decline in molecular weight until polymer integrity cannot be maintained [102]. (iv) Polymer erosion that occurs when polymer molecules break and dissolve in other mediums $[103,104]$. Schematic illustration of all processes is shown in Fig. 2. 

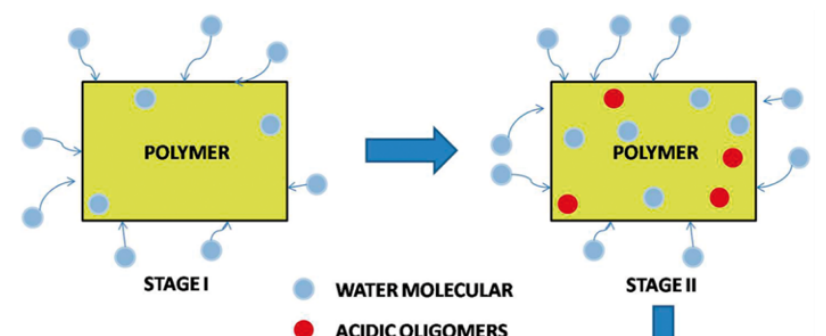

aCIDICOUIGOMERS
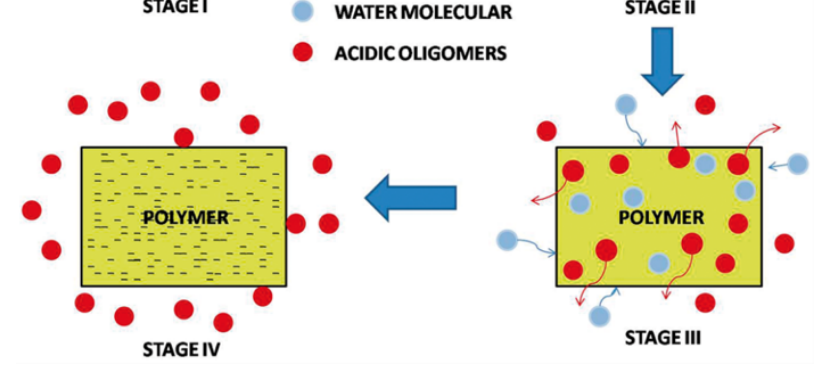

Fig. 2. Schematic illustration of a hydrolytic degradation process in polymer. [Reproduced from ref. [105]

Lu and coworkers [106] have observed the degradation process of three silk fiber films that have different crystalline and structural contents, and are insoluble in enzyme solutions. They report that the mechanism of degradation is related to crystal content, crystal structure, and hydrophilic interactions. The degradation process starts in the hydrophilic group. The next step is to convert the hydrophobic crystal group into free particles which then move into solution. Before this change occurs, the hydrophobic group is surrounded and mobilized by the hydrophilic group. Many researchers [52,106,107] have reported that silk fibers with a crystalline structure (silk II) degrade more slowly than non-crystalline and silk structures I. In this case, the first degradation process occurs in silk I, which is in crystal structure and non-crystalline unstable. Degradation occurs in protease XIV solution, producing II crystals with a high crystalline structure $[52,106]$. In silk fibroin with water-annealed and stretching treatment, it was observed that there was a change in surface morphology during the degradation process as shown in Fig. 3 [106].

In silk fibroin films with water-annealed, stretching, and slow drying treatment, the non-crystalline structure is degraded first, resulting in the termination of the filaments that envelop the core. Consequently, the formation of nuclei is free. The phenomenon reported by $\mathrm{Lu}$ et al [106] corroborates the reports of other researchers [108-110] who have reported that non-hydrophilic crystals degraded earlier before hydrophobic crystal groups. The process causes hydrophobic crystals to turn into free particles which should not be degraded in solution. Schematic illustration of the silk fibroin degradation mechanism shown in Fig. 4

\subsection{Degradation behavior by enzymes}

The biodegradation process and its mechanism are strongly influenced by physical, chemical and biological factors. The degradation behavior of silk fibroin is often facilitated by other object responses [111,112], and does not lead to an immunogenic response. In many literatures, degradation of silk fibroin is reported to be enzymatically degraded [113$115,89]$ because of the dominant role of enzymes in the degradation process of silk fibroin. Based on this fact, the enzymatic degradation process can be divided into two steps, namely enzyme adsorption on the substrate surface, and ester bond hydrolysis $[115,89]$. Silk fibroin is very sensitive to degradation by proteolytic enzymes such as carboxylase and actinase $[114,85,116]$. The stages of degradation in this type can be explained below. In the early stages, different enzymes absorb silk material to get a zone as a binder on the surface of the silk material. The next stage is the digestion of silk material by enzymes $[117,114]$.
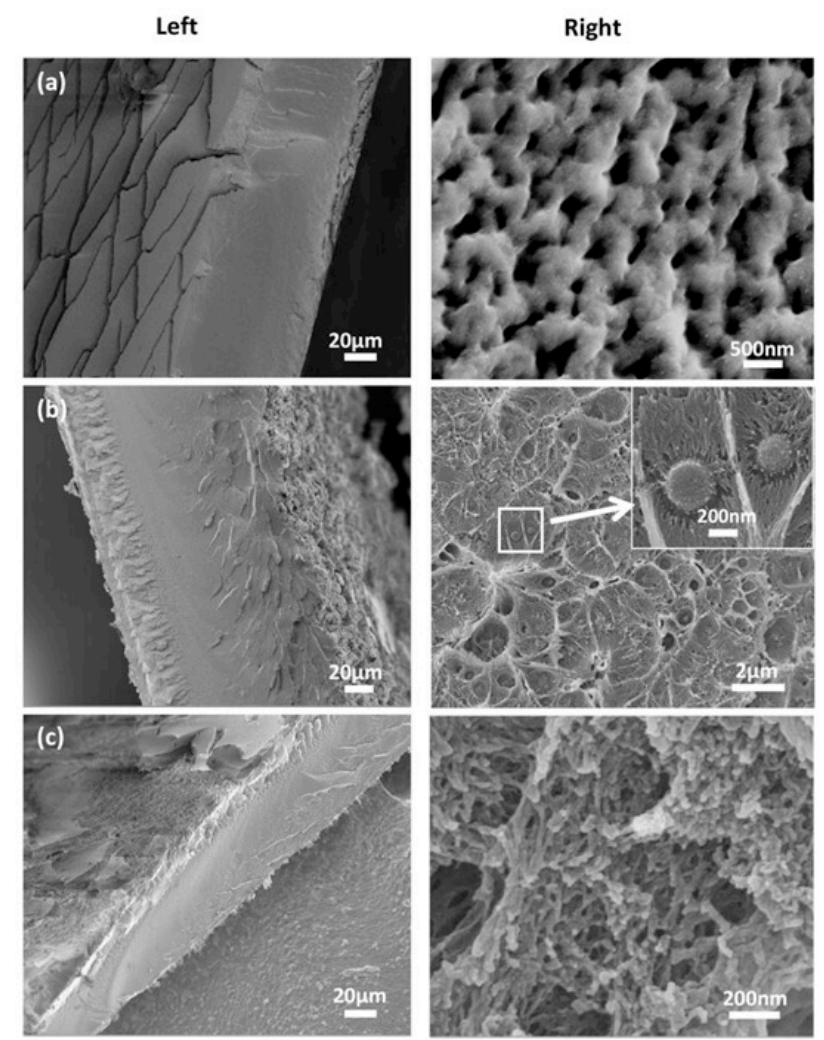

Fig. 3. Surface morphology of the silk fibroin degraded area in protease XIV solution for 720 minutes prepared by slow drying (a), waterannealed (b), and stretching treatment. Morphology with high magnification is shown in SEM images on the right side. [Reproduced from ref. 106].

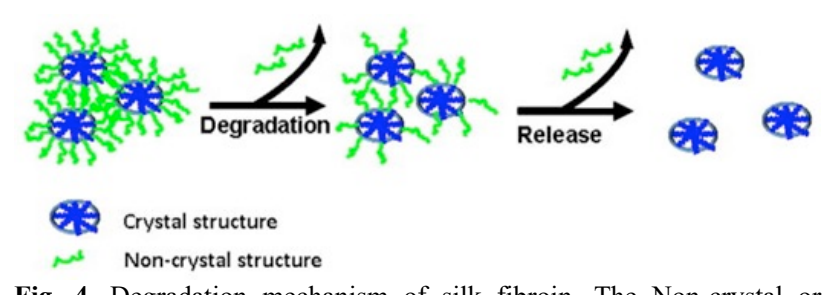

Fig. 4. Degradation mechanism of silk fibroin. The Non-crystal or unstable crystal structures were firstly degraded in enzyme solutions, resulting in the formation of free crystal structure. Then the crystal structure was dissolved in enzyme solutions [106].

Each of the different enzymes has a different impact on silk fibroin degradation behavior. Amorphous regions of silk fibroin have been successfully degraded through the use of chymotrypsin in order to obtain silk fibroin proteins with a high degree of crystallization [114,118]. Soluble silk fibroin proteins are reported to be degraded by $\alpha$-chymotrypsin [114]. It was also reported that protease XIV was extensively degraded on sheets of silk fibroin which indicated that proteases were potentially degraded from silk fibers.

Several in vitro studies $[119,110]$ of silk degradation behavior with proteolytic enzymes have been carried out. They reported that low crystalline protein regions were split into peptides which facilitated subsequent cell metabolism. Other researchers $[119,120]$ also reported that the membrane surface of silk fibroin was degenerated by protease E. Some 
researchers $[117,121]$ has reported that sheets of silk fibroin immersed in various solutions of proteolytic enzymes showed that protease XIV and Collagenase IA were able to degrade silk fibroin with a crystalline structure Silk II. While the increase in crystallization is directly proportional to the increase in time occurring in silk fibroin with the crystalline structure of Silk I. Also, it has been reported that $\alpha$ Chymotrypsin decreases the crystallinity of silk $[119,122,110]$, though, it has no serious effect on the degradation of silk.

\subsection{Silk Fibroin Degradation due to UV irradiation}

The researchers were very interested in the degradation process of fibrin due to ultraviolet (UV) radiation. From the results of the tracking it can be seen that in 1996, Yanagi et al. [123] have reported the results of their investigation of the degradation process in silk. They proposed modeling the oxidation of fibrin to $\alpha$-keto-acida. In 2005, Shao et al. prove that the tyrosine content and the degree of crystallinity decrease during aging caused by UV [124]. Previously, Sashina et al. [125] announced their proposal for the mechanism of tyrosine oxidation which could explain the yellowing phenomenon of silk. The researchers also reported the same thing that the polymer chain length was reduced by the breaking of C-N bonds in the peptide chain. According to them, ozone can also trigger the process of degradation of silk fibroin in the formation of amino groups and carboxylates [126].

It has become common knowledge that commonly used polymers are degraded under the influence of UV. The polymer response to UV radiation exposure is an important area of research especially for polymers which use in UV irradiated environments. This exposure may cause significant degradation of the polymeric material. The UV radiation causes photooxidative degradation $[127,128]$ resulting in the breaking of the polymer chain resulting in deterioration of mechanical properties $[129,130]$. Biodegradation of dissolved silk can be monitored using UV spectroscopy $[131,132]$. This tool is also used to measure the yellowish index in samples exposed to UV radiation [133].

In previous studies, it has been reported that electron spin resonance was used to study the influence of UV light, including UVA, UVB, and UVC, on spider draglines $[134,135]$. It has also been reported that UVA mechanically corroborated the diurnal spider draglines of Nc. spider [136] in spite of the fact that its impact on energy of mechanical breaking is not explored. The influence of UV light on the energy of mechanical breaking of the diurnal and nocturnal spider silk has been explored by Osaki et al [137]. They reported that UV can strengthen the diurnal draglines of N.clavata, L. blanda, and A. bruennichii. However, UV mechanically weakens the draglines of Y. sia nocturnal and N. nautica.

In terms of silk degradation, Koperska et al. [35] have proposed schematically the Silk degradation pathway by emphasizing changes in primary structure as shown in Fig. 5. This scheme was built based on various previous studies. Hydrolysis and oxidation potentially affect the state of amino acid chains. The carbonyl and amine groups are formed by the presence of peptide bonds in the amorphous zone when high humidity is reached [138]. At a relative humidity of about $65 \%$, hydrophilic silk is naturally bound by water $[138,139]$. In alkaline conditions, alkali hydrolysis occurs from the end of the peptide chain and takes place more slowly than the process in the acidic region [140]. In acid hydrolysis, both hydrogen bonds and disulfide one are used to disrupt the process so that the primary, secondary and tertiary structures are more irregular.

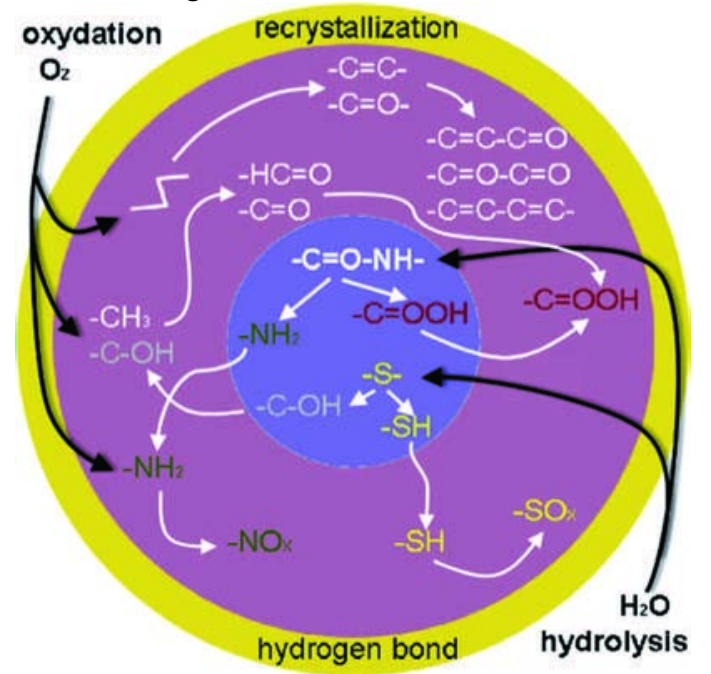

Fig. 5. Silk's (fibroin's) degradation pathway scheme. Reproduced from ref. [37].

The effects of daylight on silk can be emulated with ultraviolet (UV) irradiation. Despite the different ways, this UV irradiation produces the same effect on the structure and properties of silk [103]. Its resistance to UV is one of the physicochemical properties that becomes an important consideration in supporting its application. In addition, its resistance to UV radiation is one of the physicochemical properties that becomes an important consideration in supporting its application. Silkworm silk fiber has been widely used as a biomaterial [4, 141-143]. Osaki et al $[135,136]$ have made observations on spider silk Nephila clavata $(\mathrm{Nc})$ using spin electron resonance. The results show that $\mathrm{Nc}$ is more resistant to $\mathrm{UV}$ radiation compared with the Bombyx mori silk fiber.

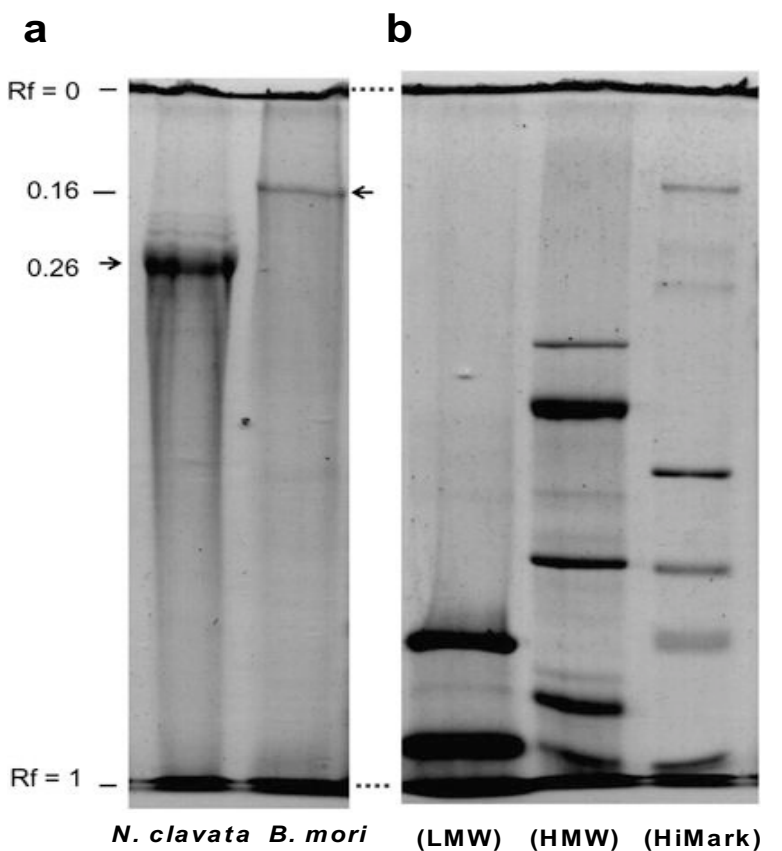

Fig. 5. Band densities of (a) Nephila clavata spider silk and Bombyx mori silkworm silk, and (b) three kinds of molecular-weight. Sample was examined using SDS PAGE prepared before UV irradiation, and the silk protein bands in the image are shown by arrows. [146].

The very interesting nature of silk is its bioactive, i.e., its ability to integrate with functional parts in the body to 
produce functional materials [144]. Wanpeng Liu et al [145] have been investigated the UV-reactive silk $\mathrm{L}_{\mathrm{L}}$-fibroin doping and its stabilization model using the horseradish peroxidase (HRP) enzyme and its bioactivities as the effect of the process of UV-reactive silk L-fibroin photolithography. The bioactivity of sample attached in biological molecules to UV with HRP doping model shift blue after exposure to tetramethylbenzidine during UV-

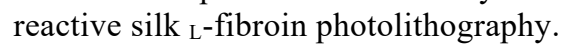
Effect on molecular weight.
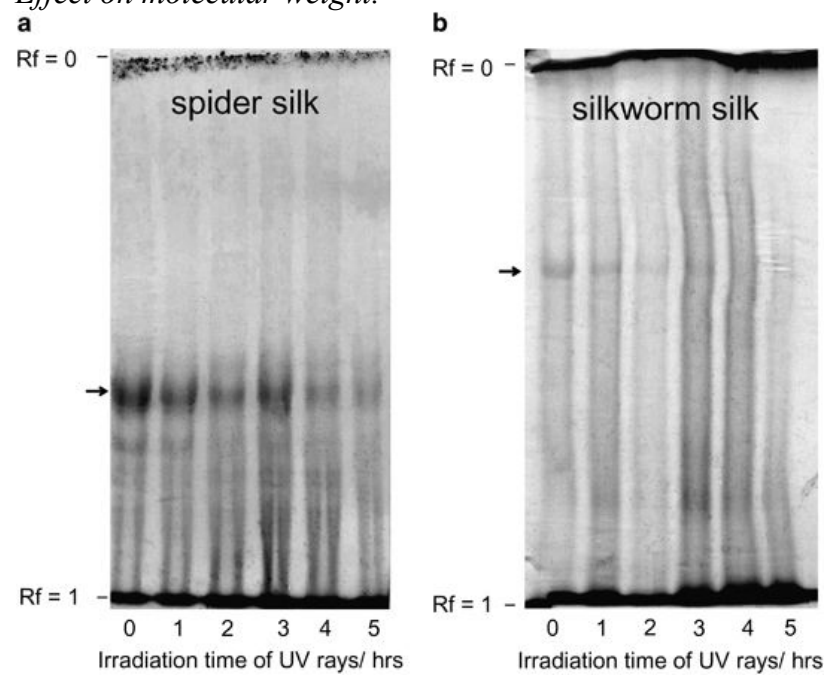

Fig. 6. Band densities of (a) Nephila clavata spider silk, and (b) Bombyx mori silkworm. The samples prepared after UV irradiation for various time duration [146].

Matsuhira et al [146] have proved that the weight of Nc spider silk molecules is more resistant to UV radiation than silkworm silk. This is thought to be caused by the amino acid chain and molecular orientation as well as the $\beta$-sheet structure. In biodegradable polymers like polycaprolactone (PCL), molecular weight reduction has a prominent effect on the capability of cell adhesives and proliferation rates by transform surface roughness and stiffness. It is also shown that long-term UV radiation can cut off the polymer chains which can ultimately alter crystallinity and other mechanical properties. Cell interactions can be increased by diversified the molecular weight $[147,148]$. Matsuhira [146] reported that the density of silkworm bands observed using SDSPAGE is decreased with increasing UV irradiation times. This phenomenon shows the occurrence of decomposition due to the cleavage of protein chain molecules. It was also reported that the degradation rate was constant as a result of UV radiation for silkworms larger than $\mathrm{N}$. clavata spider. Sionkowska and Planecka [149] have investigated the effects of UV radiation on regenerated silk fibers dissolved in water using UV-Vis spectroscopy. They found a change in the molecular weight of the silk after it was exposed to UV radiation as indicated by SDS-PAGE chromatography.

\section{Conclusion}

In order to meet the demands of the application of silk fibroin as a biomaterial, biodegradability is one of the important properties that requires in-depth study. Fibroin functions as a core consisting of $\beta$-sheet crystal regions that are highly organized and are the main element of silk fiber. Silk fibroin can be degraded enzymatically, therefore enzymes are the main actors in the process of degradation of silk fibers. In the case of the application of silk fibroin as a biomaterial, it is very important to control the degradation behavior. For example, the degradation rate of the scaffold must be controlled so that it matches the rate of tissue growth. The process of development of degradation varies, depending on the factors associated with structural and morphological silk fibroin. Other factors that play a role are protease inhibitors produced by silk itself, and ultraviolet radiation.

\section{Aknowledgement}

The author thanks the Indonesian Ministry of Research, Technology and Higher Education for financial support in this work.

This is an Open Access article distributed under the terms of the Creative Commons Attribution License

\section{References}

1. Dua, S, Jin Zhang, J., Zhou, W.T., Li, Q.L., Greene, G.W., Zhu, H.J., Li, J.L., Wang, X.G., Interactions between fibroin and sericin proteins from Antheraea pernyi and Bombyx mori silk fibers, Journal of Colloid and Interface Science, Vol. 478, pp. 316-323 (2016)

2. Collin, M.A., Mita, K., Sehnal, F., and Hayashi, C.Y., Molecular Evolution of Lepidopteran Silk Proteins: Insights from the Ghost Moth, Hepialus californicus, J Mol Evol. 70, PP. 519-529 (2010).

3. Martínez, D.C.C., Zuluaga, C.L., Restrepo-Osorio, A., ÁlvarezLópez, C., Characterization of sericin obtained from cocoons and silk yarns, Procedia Engineering, Vol. 200, PP. 377-383 (2017)

4. Melke, J., Midha, S., Ghosh, S., Ito, K., Hofmann S. Silk fibroin as biomaterial for bone tissue engineering. Acta Biomater, vol. 31, pp. 1-16 (2016)

5. X. Du, Y. Wang, L. Yuan, Y. Weng, G. Chen, Z. Hu, Colloids Surf. B: Biointerfaces122 79 (2014).

6. Xie, H., Gu, Z., Li, C., Franco, C., Wang, J., Li, L., Meredith, N., Ye, Q., Wan, C., A novel bioceramic scaffold integrating silk fibroin in calcium polyphosphate for bone tissue engineering, Ceramics International, vol.42(2), Part A, pp. 2386-2392 (2016).

7. Yin, A., Li, J., Bowlin, G.L., Li, D., Rodriguez, I.A., Wang, J., Wu, T., Ei-Hamshary, H.A., Al-Deyab, S.S., Mo, X., Colloids Surf. B: Biointerfaces 120, 47 (2014).

8. Farokhi, M., Mottaghitalab, F., Samani, S., Shokrgozar, M.A., Kundu, S.C., Reis, R.L., Fatahi, Y., Kaplan, D.L., Silk fibroin/hydroxyapatite composites for bone tissue engineering, Biotechnology Advances, vol.36(1), pp. 68-91 (2018).

9. Lu, G., Liu, S., Lin, S., Kaplan, D.L., Lu, Q., Colloids Surf. B: Biointerfaces 120, 28 (2014).

10. Fan, L., Cai, Z., Zhang, K., Han, F., Li, J., He, C., Mo, X., Wang, X., Wang, H., ColloidsSurf. B: Biointerfaces 117, 14 (2014).

11. Deng, M., Huang, Z., Zou, Y., Yin, G., Liu, J., Gu, J., Colloids Surf. B: Biointerfaces 116, 465 (2014).

12. Andiappan, M., Sundaramoorthy, S., Panda, N., Meiyazhaban, G., Winfred, S.B., Venkataraman, G., Krishna, P., Electrospun eri silk fibroin scaffold coated with hydroxyapatite for bone tissue engineering applications, Prog. Biomater., vol. 2 (1), pp. 1-11 (2013).

13. Chung, Y.G., Tu, D., Franck, D., Gil, E.S., Algarrahi, K., Adam, R.M., Kaplan, D.L., Estrada, C.R., Mauney, J.R., PLOS ONE 9 (2014)

14. Azadi, M., Teimouri, A., Mehranzadeh, G., Preparation, characterization and biocompatible properties of chitin/silk fibroin/nanohydroxyapatite composite scaffolds prepared by freezedrying method, RSC Adv., 6, PP. 7048-7060 (2016).

15. Zou, Y., Huang, Z., Wang, Y., Liao, X., Yin, G., Gu, J., Colloids Surf. B: Biointerfaces102, 29 (2013).

16. Kumar, M.S., Natta, S., Shankar, G., Reddy, S.H., Visalakshi, D., Seshiah, G.V., Comparison between Silk Sutures and Cyanoacrylate 
Adhesive in Human Mucosa- A Clinical and Histological Study, J Int Oral Health, vol. 5(5), pp. 95-100 (2013).

17. Patra, C., Talukdar, S., Novoyatleva, T., Velagala, S.R., Mühlfeld, C., Kundu, B., Kundu, S.C., and Engel, F.B., Silk protein fibroin from Antheraea mylitta for cardiac tissue engineering, Biomaterials, vol. 33(9), pp. 2673-2680 (2012).

18. Kluge, J.A., Thurber, A.E., Leisk, G.G., Kaplan, D.L., and Dorfmann, A.L., A model for the stretch-mediated enzymatic degradation of silk fibers, $\mathrm{J}$ Mech Behav Biomed Mater, 3, 7, pp. 538-547 (2010)

19. Tao, H., Kaplan, D.L., Omenetto, F.G., Silk Materials - A Road to Sustainable High Technology Adv. Mater., vol.24, 2824 (2012).

20. Mwangi, T.K., Bowles, R.D., Tainter, D.M., Bell, R.D., Kaplan, D.L and Setton, L.A., Synthesis and Characterization of Silk Fibroin Microparticles for Intra-Articular Drug Delivery, Int J Pharm., vol. 48, pp. 7-14 (2015).

21. Altman, G.H., Diaz, F., Jakuba, C., Calabro, T., Horan, R.L., and Chen, J., Biomaterials, vol. 24, 401 (2003).

22. Pignatelli, C., Perotto, G., Nardini, M., Cancedda, R., Mastrogiacomo, M., and Athanassiou, A., Electrospun silk fibroin fibers for storage and controlled release of human platelet lysate, Acta Biomaterialia, vol. 73, pp. 365-376 (2018).

23. Pal, R.K., and Yadavalli, V.K., Silk protein nanowires patterned using electron beam lithography, Nanotechnology, vol. 29(33), 335301 (2018).

24. Qin, N., Zhang, S., Jiang, J., Corder, S.G., Qian, Z., Zhou, Z., Lee, W., Liu, K., Wang, X., Li, X., Shi, Z., Mao, Y., Bechtel, H.A., Martin, M.C., Xia, Z., Marelli, B., Kaplan, D.L., Omenetto, F.G., Liu, M., and Tao, T.H., Nat. Commun., vol. 7, 13079 (2016).

25. Kim, S.H., Yeon, Y.K., Lee, J.M., Chao, J.R., Lee, Y.J., Seo, Y.B., Sultan, M.T., Lee, Lee, J.S., Yoon, S., Hong, I-S., Khang, G., Lee, S.J., Yoo, J.J., and Park, C.H., Precisely printable and biocompatible silk fibroin bioink for digital light processing 3D printing, Nature Communications, vol. 9, 1620 (2018).

26. Rodriguez, M.J., Dixon, T.A., Cohen, E., Huang, W., Omenetto, F.G., and Kaplan, D.L., 3D freeform printing of silk fibroin, Acta Biomaterialia, vol. 71, pp.379-387 (2018).

27. Tsioris, K., Raja, W.K., Pritchard, E.M., Panilaitis, B., Kaplan, D.L., and Omenetto, F.B., Fabrication of silk microneedless for controlledreleased drug delivery, Adv. Funct. Mater., vol. 22, 330-335 (2012).

28. Sun, K., Li, R., Li, H., Li, D., and Jiang, W., Comparison of threedimensional printing for fabricating silk fibroin-blended scaffolds, International Journal of Polymeric Materials and Polymeric Biomaterials, vol. 67(8), pp. 480-486 (2018)

29. Omenetto F.G., Kim, S., Eco-friendly photolithography using waterdevelopable pure silk fibroin, RSC Adv., vol.6, pp. 39330-39334 (2016)

30. Liu, W., Zhou, Z., Zhang, S., and Shi, Z., Biopatterning: Precise Protein Photolithography (P 3 ): High Performance Biopatterning Using Silk Fibroin Light Chain as the Resist, Advanced Science 4(9) (2017)

31. Gates, B.D., Xu, Q.B., Stewart, M., Ryan, D., Willson, C.G., and Whitesides, G.M., Chem. Rev. vol. 105, pp. 1171 (2005)

32. Ribeiro, V.P., Morais, A.S., Maia, F.R., Canadas, R.F., Costa, J.B., Oliveira, A.L., Oliveira, J.M., Reis, R.L., Combinatory approach for developing silk fibroin scaffolds for cartilage regeneration, Acta Biomaterialia, vol. 72, pp. 167-181, (2018).

33. Warnecke D, Stein S, Haffner-Luntzer M, de Roy L, Skaer N, Walker R, Kessler O, Ignatius A, Dürselen L., Biomechanical, structural and biological characterisation of a new silk fibroin scaffold for meniscal repair, J Mech Behav Biomed Mater., vol. 86, pp.314-324 (2018)

34. Raphel, J., Parisi-Amon, J., Heilshorn, S.C., Photoreactive elastinlike proteins for use as versatile bioactive materials and surface coatings, J. Mater. Chem., vol. 22, pp. 19429-19437 (2012)

35. Mehrabani, M.G., Karimian, R., Mehramouz, B., Rahimi, M., and Kafil, H.S., Preparation of biocompatible and biodegradable silk fibroin/chitin/silver nanoparticles 3D scaffolds as a bandage for antimicrobial wound dressing, International Journal of Biological Macromolecules, vol. 114, pp. 961-971 (2018).

36. Koperska, M.A., Pawcenis, D., Bagniuk, J., Łojewski, T., and Łojewska, J., Degradation markers of fibroin in silk through infrared spectroscopy, Polym. Degrad. Stab. 105 (2014) 185-196.

37. Koperska, M.A., Łojewski, T., and Łojewska, J., Evaluating degradation of silk's fibroin by attenuated total reflectance infrared spectroscopy: case study of ancient banners from Polish collections, Spectrochim. Acta A Mol. Biomol. Spectrosc. 135 (2015) 576-582.

38. Luangbudnark, W., Viyoch, J., Laupattarakasem, W., Surakunprapha, P., and Laupattarakasem, P., Properties and
Biocompatibility of Chitosan and Silk Fibroin Blend Films for Application in Skin Tissue Engineering, The Scientific World Journal, vol. 2012, 697201 (2012).

39. Hu, Y., Zhang, Q., You, R., Wang, L., and Li, M., The relationship between secondary structure and biodegradation behaviour of silk fibroin scaffolds, Adv. Mater. Sci. Eng., vol. 2012, pp.1-5 (2012).

40. Li, Z.H., Ji, S.C., Wang, Y-Z., Shen, X-C., and Liang, H., Silk fibroin-based scaffolds for tissue engineering, Frontiers of Materials Science, vol. 7(3) (2013)

41. Yazawa, K., Ishida, K., Masunaga, H., Hikima, T., and Numata, K., Influence of Water Content on the $\beta$-Sheet Formation, Thermal Stability, Water Removal, and Mechanical Properties of Silk Materials, Biomacromolecules, vol. 17(3), pp 1057-1066 (2016)

42. Jiang, C.Y., Wang, X.Y., Gunawidjaja, R., Lin, Y.H., Gupta, M.K., Kaplan, D.L., Naik, R.R., and Tsukruk, V.V., Adv Funct Mater., vol.17, pp. 2229 - 2237 (2007).

43. Pereira, R.F.P., Brito-Pereira, R., Gonçalves, R., Silva, M.P., Costa, C.M., Silva, M.M., Bermudez, V.Z., and Lanceros-Méndez, S., Silk Fibroin Separators: A Step Toward Lithium-Ion Batteries with Enhanced Sustainability, ACS Appl. Mater. Interfaces, vol. 10(6), pp 5385-5394 (2018)

44. Min, K., Kim, S., and Kim, S., Silk protein nanofibers for highly efficient, eco-friendly, optically translucent, and multifunctional air filters, Scientific Reportsvolume 8, 9598 (2018)

45. Wang, Y., Wang, X., Shi, J., Zhu, J., Zhang, J., Zhang, Z., Ma, D., Hou, Y., Lin, F., Yang, J., and Mizuno, M., A Biomimetic Silk Fibroin/Sodium Alginate Composite Scaffold for Soft Tissue Engineering, Scientific Reports, vol. 6, 39477 (2016)

46. Alessandrino, A., Marelli, B., Arosio, C., Fare, S., Tanzi, M.C., Freddi, C., Electrospun Silk Fibroin Mats for Tissue Engineering, Eng Life Sci. Vol. 8, pp. 219-225 (2008).

47. Wang, X., Kluge, J.A., Leisk, G.G., Kaplan, D.L., Sonicationinduced gelation of silk fibroin for cell encapsulation, Biomaterials. Vol. 29(8), pp.1054-1064 (2008).

48. Burke, K.A., Roberts, D.C., and Kaplan, D.L., Silk Fibroin AqueousBased Adhesives Inspired by Mussel Adhesive Proteins, Biomacromolecules, vol. 17(1): 237-245 (2016)

49. Kim, H.J., Kim, U.J., Kim, H.S., Li, C.M., Wada, M., Leisk, G.G., Kaplan D.L., Bone tissue engineering with premineralized silk scaffolds, Bone, vol. 42, pp. 1226-1234 (2008)

50. Li, S., Yu, D., Ji, H., Zhao, B., Ji, L. and Leng, X., In vivo degradation and neovascularization of silk fibroin implants monitored by multiple modes ultrasound for surgical applications, BioMedical Engineering OnLine, vol. 17(1), pp. 87 (2018)

51. Carvalho, M.R., Maia, F.R., Vieira, S, Reis, R.L., Oliveira, J.M., Tuning Enzymatically Crosslinked Silk Fibroin Hydrogel Properties for the Development of a Colorectal Cancer Extravasation 3D Model on a Chip, vol. 2(5-6), 1700100 (2018)

52. Lu, Q., Hu, X., Wang, X.Q., Kluge, J.A., Lu, S.Z., Cebe, P., Kaplan, D.L., Water-insoluble silk films with silk I structure, Acta Biomaterialia, vol. 6(4), pp.1380-1387 (2010).

53. Vepari, C., and Kaplan, D,I, Silk as a Biomaterial, Prog Polym Sci. vol. 32(8-9), pp. 991-1007 (2007)

54. Drummy L.F., Phillips D.M., Stone M.O., And B.L.F., Naik R.R. Thermally Induced $\alpha$-Helix to $\beta$-Sheet Transition in Regenerated Silk Fibers and Films. Biomacromolecules, vol.6, pp. 3328-3333 (2005).

55. Numata, K., Cebe, P., and Kaplan, D.L., Mechanism of enzymatic degradation of beta-sheet crystals. Biomaterials., vol. 31, pp. 29262933 (2010)

56. Qi, Y., Wang, H., Wei, K., Yang, Y., Zheng, R-Y., Kim, I.S., and Zhang, K-Q., A Review of Structure Construction of Silk Fibroin Biomaterials from Single Structures to Multi-Level Structures, Int J Mol Sci. vol. 8(3), pp. 237 (2017).

57. Kundu, S.C., Kundu, B., Talukdar, S., Bano, S., Nayak, S., Kundu, J., Mandal, B.B., Bhardwaj, N., Botlagunta, M., Dash, B.C., Acharya, C., and Ghosh, A.K., Invited review nonmulberry silk biopolymers, Biopolymers vol. 97(6), pp. 455-467 (2012).

58. Weiner, S., Traub,W., and Wagner, H.D., Lamellar Bone: StructureFunction Relations. J. Struct. Biol.vol. 126, pp. 241-255 (1999)

59. Aubin-Tam, M.E., and Hamad-Schifferli, K., Structure and function of nanoparticle-protein conjugates. Biomed. Mater., vol. 3, 34001(2008).

60. Badylak, S.F., Freytes, D.O., and Gilbert, T.W., Extracellular matrix as a biological scaffold material: Structure and function. Acta Biomater., vol. 5, pp. 1-13 (2009).

61. Ramirez, M. A., Chen, Z. Synthesis of an Intein-mediated Artificial Protein Hydrogel. J. Vis. Exp. (83), e51202 (2014). 
62. Asakura, T., Yao, J., Yamane, T., Kosuke, U., and Ulric, H.S., Heterogeneous structure of silk fibers from Bombyx mori resolved by 13 C solid-state NMR spectroscopy. J. Am. Chem. Soc. Vol. 124, pp. 8794-8795 (2002).

63. Kim, U.J., Park, J., Kim, H.J., Wada, M., and Kaplan, D.L. Three dimensional aqueous-derived biomaterial scaffolds from silk fibroin. Biomaterials, vol. 26, pp. 2775-2785 (2005).

64. Lee, J.H., Bae, C.Y., Park, B.D., and Um, I.C., Preparation of Cellulose Nanofibril/Regenerated Silk Fibroin Composite Fibers, Int. J. Indust. Entomol., vol. 26(2), pp. 81-88 (2013)

65. de Moraes, M.A., Crouzier, T., Rubner, M., and Beppu, M.M., Factors Controlling the Deposition of Silk Fibroin Nanofibrils during Layer-by-Layer Assembly, Biomacromolecules, vol.16 (1), pp 97104 (2015)

66. Park, Y.R., Ju, H.W., Lee, J.M., Kim, D-K, Lee, O.J., Moon, B.M., Park, H.J., Jeong, J.Y., Yeon, Y.K., and Park, C.H., Threedimensional electrospun silk-fibroin nanofiber for skin tissue engineering, International Journal of Biological Macromolecules, vol. 93, Part B, pp.1567-1574 (2016).

67. Oroudjev, E., Soares, J., Arcidiacono, S., Thompson, J.B., Fossey, S.A., and Hansma, H.G., Segmented nanofibers of spider dragline silk: atomic force microscopy and single-molecule force spectroscopy. Proc. Natl. Acad. Sci. USA., vol. 99, pp. 6460-6465 (2002).

68. Bai, S., Liu, S., Zhang, C., Xu, W., Lu, Q., Han, H., Kaplan, D.L., and Zhu, H., Controllable transition of silk fibroin nanostructures: an insight into in vitro silk self-assembly process, Acta Biomater., vol. 9(8), pp. 7806-7813 (2013)

69. Sapede, D., T. Seydel, V. T. Forsyth, M. M. Koza, R. Schweins, F. Vollrath, and C. Riekel. 2005. Nanofibrillar structure and molecular mobility in spider dragline silk. Macromolecules. 38:8447-8453.

70. Kishimoto, Y., Ito, F., Usami, H., Togawa, E., Tsukada, M., Morikawa, H., and Yamanaka, S., Nanocomposite of silk fibroin nanofiber and montmorillonite: Fabrication and morphology, International Journal of Biological Macromolecules, vol. 57, pp. 124-128 (2013).

71. Lefèvre, T., Rousseau, M.E., and Pézolet, M., Protein secondary structure and orientation in silk as revealed by Raman spectromicroscopy, Biophys J., vol. 92(8), pp. 2885-95 (2007).

72. Murphy, A.R., and Kaplan, D.L., Biomedical applications of chemically-modified silk fibroin. J Mater Chem, vol.19, pp. 64436450 (2009).

73. Tsuboi, Y., Ikejiri, T., Shiga, S., Yamada, K., and Itaya, A., Light can transform the secondary structure of silk protein. Appl. Phys. A, vol. 73, pp. 637-640 (2001).

74. Koperska, M.A., Pawcenis, D., Bagniuk, J., Degradation markers of fibroin in silk through infrared spectroscopy, Polymer Degradation and Stability, vol. 105, pp. 185-196 (2014).

75. Purnomo, Setyarini, P.H., and Mukaromah, A.H., The potential of silk fibroin as a polymer composite reinforcement for bone implant materials, MATEC Web of Conferences 204, 05017 (2018)

76. Cao, Y., and Wang, B., Biodegradation of silk biomaterials, International Journal of Molecular Sciences, vol. 10(4), pp. 15141524 (2009)

77. Zhang, K., Yin, A., Huang, C., Degradation of electrospun SF/P(LLA-CL) blended nanofibrous scaffolds in vitro, Polymer Degradation and Stability, vol. 96 (12), pp. 2266-2275 (2011).

78. Pritchard, E.M., Hu, X., Finley, V., Kuo, C.K., and Kaplan, D.L., Effect of silk protein processing on drug delivery from silk films, Macromolecular Bioscience, vol. 13(3), pp. 311-320 (2013).

79. Lu, Q., Zhang, B., Li, M., Zuo, B., Kaplan, D.L, Huang, Y., and Zhud, H., Degradation mechanism and control of silk fibroin, Biomacromolecules, vol. 12, no. 4, pp. 1080-1086 (2011).

80. Rajkhowa, R., Hu, X., Tsuzuki, T., Kaplan, D.L., and Wang, X., Structure and biodegradation mechanism of milled Bombyx mori silk particles, Biomacromolecules, vol. 13(8), pp. 2503-2512 (2012)

81. Kim, J.H., Park, C.H., Lee, O.-J., Kim, J.W., Park, Y.H., and Ki, C.S., Preparation and in vivo degradation of controlled biodegradability of electrospun silk fibroin nanofiber mats, Journal of Biomedical Materials Research Part A, vol. 100(12), pp. 32873295 (2012)

82. Li, X.F., Zhang, C., Wang, L.S., Ma, C.L., Yang, W.C., and Li, M.Z., Acylation modification of Antheraea pernyi silk fibroin using succinic anhydride and its effects on enzymatic degradation behavior, Journal of Chemistry, vol. 2013, 640913 (2013).

83. Cheung, H.-Y., Lau, K.-Y., Pow, Y.-F., Zhao, Y.-Q., and Hui, D., Biodegradation of a silkworm silk/PLA composite, Composites Part B: Engineering, vol. 41(3), pp. 223-228 (2010).
84. Zuo, B., Dai, L., and Wu, Z., Analysis of structure and properties of biodegradable regenerated silk fibroin fibers, Journal of Materials Science, vol. 41(11), pp. 3357-3361 (2006).

85. Brown, J., Lu, C.-L., Coburn, J., and Kaplan, D.L., Impact of Silk Biomaterial Structure on Proteolysis, Acta Biomater., vol. 1(11), pp. 212-221 (2015).

86. Zou, B., and Wu, D.Z., Analysis of structure and properties of biodegradable regenerated silk fibroin fibers. J. Mater. Sci., vol. 41, pp. 3357-3361 (2006).

87. Luo, Z., Zhang, Q., Shi, M., Zhang, Y., Tao, W., and Li, M., Effect of Pore Size on the Biodegradation Rate of Silk Fibroin Scaffolds, Advances in Materials Science and Engineering, vol. 2015, 315397 (2015).

88. Murphy, A.R., and Kaplan, D.L., Biomedical applications of chemically-modified silk fibroin, J Mater Chem., vol. 19(36), pp. 6443-6450 (2009).

89. Chen, J., Venkatesan, H., Hu, J., Chemically Modified Silk Proteins, Adv. Eng. Mater., vol. 20, 1700961 (2018).

90. Simmons, L., Tsuchiya, K., and Numata, K., Chemoenzymatic modification of silk fibroin with poly(2,6-dimethyl-1,5-phenylene ether) using horseradish peroxidase, RSC Adv., vol. 6, pp. 28737 28744 (2016).

91. Wray, L.S., Hu, X., Gallego, J., Georgakoudi, I., Omenetto, F.G., Schmidt, D., and Kaplan, D.L., Effect of Processing on Silk-Based Biomaterials: Reproducibility and Biocompatibility, J Biomed Mater Res B Appl Biomater. vol. 99(1), pp. 89-101 (2011).

92. Valluzzi, R., Gido, S.P., Zhang, W., Muller, W.S., Kaplan, D.L., Trigonal crystal structure of bombyx mori silk incorporating a threefold helical chain conformation found at the air-water interface. Macromolecules, vol. 29, 8606-8614 (1996).

93. Garside, P., and Wyeth, P., Crystallinity and degradation of silk: Correlations between analytical signatures and physical condition on ageing, Applied Physics A, vol. 89(4), pp. 871-876 (2007).

94. Hu, Y., Zhang, Q., You, R., Wang, L., Li, M., The Relationship between Secondary Structure and Biodegradation Behavior of Silk Fibroin Scaffolds, Advances in Materials Science and Engineering, vol. 2012(6), 185905 (2012).

95. Zhang, L., Liu, X., Li, G., Wang, P., Yang, Y., Tailoring degradation rates of silk fibroin scaffolds for tissue engineering, J Biomed Mater Res A. vol.107(1), pp. 104-113 (2019).

96. Li, G., Li, Y., Chen, G., He, J., Han, Y., Wang, X., Kaplan, D.L., Silk-based biomaterials in biomedical textiles and fiber-based implants, Adv Healthc Mater., vol. 4(8), pp. 1134-1151 (2015).

97. Hu, Y.P., Zhang, Q., You, R.C., Wang, L.S., and Li, M.Z., The relationship between secondary structure and biodegradation behavior of silk fibroin scaffolds, Advances in Materials Science and Engineering, vol. 2012, 185905 (2012).

98. Li, M., Ogiso, M., and Minoura, N., Enzymatic degradation behavior of porous silk fibroin sheets, Biomaterials, vol. 24(2), pp. 357-365 (2003).

99. You, R., Xu, Y., Liu, G., Liu, Y., Li, X., and Li, M., Regulating degradation rate of silk fibroin films through changing the genipin crosslinking degree, Polymer Degradation and Stability, vol. 109, pp. 226-232 (2014).

100.Makadia, H.K., and Siegel, S.J., Poly Lactic-co-Glycolic Acid (PLGA) as BiodegradableControlled Drug Delivery Carrier, Polymers (Basel). vol. 3(3), pp. 1377-1397 (2011).

101.Feng, Q., Tang, Q., Zhang, W., Jiad, Y., and Zhang, D., End-group Method for Molecular Weight Determination of PET Depolymerization under Microwave Irradiation, Advanced Materials, vols. 554-556, pp 1933-1937 (2012)

102.Pathak, V.M., and Navneet, Review on the current status of polymer degradation: a microbial approach, Bioresources and Bioprocessing, vol. 4, pp. 15 (2017).

103.Nilsson, J., Vilaplana, F., Karlsson, S., Bjurman, J., Iversen, T., The validation of artificial ageing methods for silk textiles using markers for chemical and physical properties of seventeenth-century silk. Stud Conserv., vol. 55, pp. 55-65 (2010)

104.Lyu, S., and Untereker, D., Degradability of Polymers for Implantable Biomedical Devices, Int J Mol Sci., vol. 10(9), pp. 40334065 (2009).

105.Li, Y., Chu, Z., Li, X., Ding, X., Guo, M., Zhao, H., Yao, J., Wang, L., Cai, Q., and Fan, Y., The effect of mechanical loads on the degradation of aliphatic biodegradable polyesters, Regen Biomater., vol. 4(3), pp. 179-190 (2017).

106.Lu, Q., Zhang, B., Li, M., Zuo, B., Kaplan, D.L., Huang, Y., and Zhud, H., Degradation Mechanism and Control of Silk Fibroin, Biomacromolecules., vol. 12(4), pp. 1080-1086 (2011) 
107.Jin, H.J., Park, J., Karageorgiou, V., Kim, U.J., Valluzzi, R., Cebe, P., Kaplan, D.L., Adv Funct Mater., vol.15, pp. 1241-1247 (2005)

108.Horan, R.L., Antle, K., Collette, A.L., Wang, Y.Z., Huang, J., Moreau, J.E., Volloch, V., Kaplan, D.L., Altman, G.H., In vitro degradation of silk fibroin, Biomaterials., vol. 26, pp. 3385-3393 (2005)

109.Wang, Y., Rudym, D.D., Walsh, A., Abrahamsen, L., Kim, H., Kim, H.S., Kirker-Head, C., Kaplan, D.L., In vivo degradation of threedimensional silk fibroin scaffolds., Biomaterials, vol. 29, pp. 3415 3428 (2008).

110.Ubaldo, A., Ilaria, D.P., Anna, C., Giuliano, F., Will silk fibroin nanofiber scaffolds ever hold a useful place in Translational Regenerative Medicine? Int J Burn Trauma, vol. 1(1), pp. 27-33 (2011)

111.Altman GH, Diaz F, Jakuba C, Calabro T, Horan RL, Chen J, Lu H, Richmond J, Kaplan DL. Silk-based biomaterials. Biomaterials. 2003;24(3):401-416.

112. You, R. , Zhang, Y. , Liu, Y., Liu, G. and Li, M., The degradation behavior of silk fibroin derived from different ionic liquid solvents. Natural Science, vol. 5, pp. 10-19 (2013).

113.Arai, T., Freddi, G., Innocenti, R., Tsukada, M., Biodegradation of Bombyx mori Silk Fibroin Fibers and Films. J Appl Polym Sci. vol. 91, pp. 2383-2390 (2004).

114.Li, M., Ogiso, M., Minoura, N., Enzymatic degradation behavior of porous silk fibroin sheets. Biomaterials, vol. 24, pp. 357-365 (2003).

115.Xu, Y., Wang, Y., Jiao, Y., Zhang, C., Li, M., Enzymatic Degradation Properties of Silk Fibroin Film, Journal of Fiber Bioengineering and Informatics, vol. 4, pp. 35-41 (2011)

116. Srihanam, P., and Simchuer, W., Proteolytic Degradation of Silk Fibroin Scaffold by Protease XXIII, The Open Macromolecules Journal, vol. 3, pp. 1-5 (2009)

117.Cao, Y., and Wang, B., Biodegradation of Silk Biomaterials, Int. J. Mol. Sci. vol.10, 1514-1524 (2009)

118.Tao, Y., Xu, W., Yan, Y., Cao, Yu., Preparation and characterization of silk fibroin nanocrystals, Polymer International 61(5), pp.760-767 (2012).

119.Wongpinyochit, T., Johnston, and Seib, F.P., Degradation Behavior of Silk Nanoparticles-Enzyme Responsiveness, ACS Biomater. Sci. Eng.,vol. 4, pp. 942-951, (2018)

120.Wongnarat,C., Srihanam, p., Degradation Behaviors of Thai Bombyx mori Silk Fibroins Exposure to Protease Enzymes, Engineering, vol. 5, pp. 61-66 (2013)

121.Drnovšek, N., Kocen, R., Gantar, A., Drobnič-Košorok, M., Leonardi, A., Križaj, I. Rečnika, A., and Novakae, A., Size of silk fibroin $\beta$-sheet domains affected by Ca2+, J. Mater. Chem. B, vol. 4 , pp. 6597-6608 (2016).

122.Samal, S.K., Dash, M., Chiellini, F., Kaplan, D.L., Chiellini, E., Silk Microgels Formed by Proteolytic Enzyme Activity, Acta Biomater. 2013 9(9): 8192-8199.

123. Yousif, E., and Haddad, R., Photodegradation and photostabilization of polymers, especially polystyrene: review, Springerplus, vol. 2, pp. 398 (2013).

124.Luo, X., Wu, J., Intisar, A., Geng, J., Wu, L., Zheng, K., and Du, Y., Study on Light Aging of Silk Fabric by Fourier Transform Infrared Spectroscopy and Principal Component Analysis, Analytical Letters, vol. 45(10), pp. 1286-1296 (2012).

125.Sashina, E.S., Bochek, A.M., Novoselov, N.P., Kirichenko, D.A., Structure and solubility of natural silk fibroin. Russ. J. Appl. Chem., vol. 79(6), 869-876 (2006)

126. Sargunamani, D., and Selvakumar,N., Effects of ozone treatment on the properties of raw and degummed tassar silk fabrics, Journal of Polymer Science, vol.104(5), pp. 147-155 (2007)

127.Pinto, L., Goi, B., Schmitt, C., and Neumann, M.. Photodegradation of polystyrene films containing UV-visible sensitizers. Journal of Research Updates in Polymer Science., vol. 2, pp. 39-47 (2013).

128.Gijsman, P., and Diepens, M., Photolysis and photooxidation in engineering plastics, Polymer Degradation and Performance. ACS Symp Ser., vol.1004, pp. 287-306 (2009).

129.Bedia, E., Paglicawan, M., Bernas, C., Bernando, S., Tosaka, and M., Kohjiya, S.. Natural weathering of polypropylene in a tropical zone. J App Polym Sci., vol. 87, pp. 931-938 (2003).

130.Rajakumar, K., Sarasvathy, Chelvan, A.T., Chitra, R., and Vijayakumar, C.T., Natural weathering studies of polypropylene. J Polym Environ., vol. 17, pp.191-202 (2009).

131.Vilaplana, F., Nilsson, J., Sommer, D.V., and Karlsson, S., Analytical markers for silk degradation: comparing historic silk and silk artificially aged in different environments, Anal Bioanal Chem., vol. 407(5), pp. 1433-1449 (2015).

132.Balčytis, A., Ryu, M., Wang, X., Novelli, F., Seniutinas, G., Du, S., Wang, X., Li J., Davis, J., Appadoo, D., Morikawa, J., Juodkazis, S., Silk: Optical Properties over 12.6 Octaves THz-IR-Visible-UV Range, Materials, vol. 10(4), pp. 356 (2017)

133. Yanagi, Y., Kondo, Y., Hirabayashi, Y., Deterioration of Silk Fabrics and Their Crystallinity, Textile Research Journal, vol. 70(10), pp. 871-875 (2000).

134.Lepore, E., Isaia, M., Mammola, S., and Pugno, N., The effect of ageing on the mechanical properties of the silk of the bridge spider Larinioides cornutus (Clerck, 1757), Scientific Reports, vol. 6, 24699 (2016)

135.Stellwagen, S.D., Opell, B.D., Clouse, M.E., The impact of UVB radiation on the glycoprotein glue of orb-weaving spider capture thread, Journal of Experimental Biology, vol. 218: 2675-2684, (2015).

136.Lai, W.L., and Goh, K.L., Consequences of Ultra-Violet Irradiation on the Mechanical Properties of Spider Silk, J Funct Biomater. vol. 6(3), pp. 901-916 (2015)..

137. Osaki, S., and Osaki, M., Evolution of spiders from nocturnal to diurnal gave spider silks mechanical resistance against UV irradiation, Polymer Journal, vol. 43, pp. 200-204 ((2011)

138.Monti, P., Freddi, G., Sampaio, S., Tsukada, M., Structure modifications induced in silk fibroin by enzymatic treatments. A Raman study, Journal of Molecular Structure, vol. 744, pp. 685-690 $\cdot(2005)$.

139.Célino, A., Fréour, S., Jacquemin, F., and Casari, P., The hygroscopic behavior of plant fibers: a review, Front Chem., vol. 1, pp. 43 (2013).

140.McCarthy, A.F., O’Callaghan, Y.C., and O’Brien, N.M., Protein Hydrolysates from Agricultural Crops-Bioactivity and Potential for Functional Food Development, Agriculture, vol. 3, pp. 112-130 (2013)

141.Rockwood, D.N., Gil, E.S., Park, S.H., Kluge, J.A., Grayson, W., Bhumiratana, S., Rajkhowa, R., Wang, X., Kim, S.J., VunjakNovakovic. G., Kaplan. D.L., Ingrowth of human mesenchymal stem cells into porous silk particle reinforced silk composite scaffolds: An in vitro study, Acta Biomater, vol. 7(1), pp.144-51 (2011).

142.Yodmuang, S., McNamara, S.L., Nover, A.B., Mandal, B.B., Agarwal, M., Kelly, T-A., N., Chao, P-h.G., Hung, C., Kaplan, D.L., and Vunjak-Novakovic, G., Silk microfiber-reinforced silk hydrogel composites for functional cartilage tissue repair, Acta Biomater., vol. 11, pp. 27-36 (2015).

143.Behera, S., Naskar, D., Sapru, S., and Kundu, S.C., Hydroxyapatite reinforced inherent RGD containing silk fibroin composite scaffolds: Promising platform for bone tissue engineering, Nanomedicine: nanotechnology, biology, and medicine, Vol. 13(5), 2017

144.Pritchard, E.M., Dennis, P.B., Omenetto, F.G., Naik, R.R., Kaplan, D.L., Biopolymers, vol. 97, pp. 479 (2012).

145.Liu, W., Zhou, Z., Zhang, S., Shi, Z., Tabarini, J., Lee, W., Zhang, Y., Corder, Z.N.G., Li, X., Dong, F., Cheng, L., Liu, M., Kaplan, D.L., Omenetto, F.G., Zhang, G., Mao, Y., and Tao, T.H., Precise Protein Photolithography (P3): High Performance Biopatterning Using Silk Fibroin Light Chain as the Resist, Adv. Sci., vol. 4, 1700191 (2017).

146.Matsuhira, T., Yamamoto, K., and Osaki, S., Effects of UV irradiation on the molecular weight of spider silk, Polymer Journal volume, Vol. 45, pp.1167-1169 (2013)

147.Yeha, C.C., Chenb, C-N., Lib, Y-T., Chang, C-W., Cheng, M-Y., and Chang, H-I., The Effect of Polymer Molecular Weight and UV Radiation on Physical Properties and Bioactivities of PCL Films. Cellular Polymers, vol. 30(5), pp. 262-276 (2011)

148.Purnomo, Subri, M., and Setyarini, P., Fracture development and deformation behavior of zeolite-filled high density polyethylene annealed composites in the plane stress fracture, FME Transactions, vol. 46(2), pp. 165-170 (2018)

149.Sionkowska, A., and Planecka, A., The influence of UV radiation on silk fibroin, Polymer Degradation and Stability, vol. 96(4), pp. 523528 (2011)

150.Purnomo, Subri, M., and Setyarini, P., Fracture development and deformation behavior of zeolite-filled high density polyethylene annealed composites in the plane stress fracture, FME Transactions, vol. 46(2), pp. 165-170 (2018) 